\title{
Legal Protection for Children of Sexual Violence Victim in the Household
}

\author{
Ratna Komala Dewi ${ }^{1}$, Faisal Santiago ${ }^{2}$ \\ University of Borobudor ${ }^{1,2}$ \\ \{ratnaunboro@gmail.com¹, faisalsantiago@borobudur.ac.id²\}
}

\begin{abstract}
Violence against children in the household environment has certain characteristics that make it hard to enforce the law. By using normative research, which will use a descriptive type of research with a normative juridical approach, it is found that the state guarantees legal protection for children from threats of violence including violence in their families. The state is obliged to provide adequate protection for a child, efforts to protect children must be supported by the existence of an effective and comprehensive children protection law.
\end{abstract}

Keywords: Children; Victim of Violence; Legal Protection

\section{Introduction}

The realization of household harmony and integrity is highly dependent on the level of quality of behavior and self-control of everyone within the household scope. Household integrity and harmony can be disrupted if the quality of behavior and self-control cannot be controlled. The severe consequences that can result from the inability to control and control oneself are the emergence of negative behavior in the form of anger and quarrels which can lead to acts of domestic violence (KDRT).

So far, it is women (wives) who often have to suffer the consequences of violence that occurs in the household sphere. Latent victims of women tend to be victims of violence more often than men. Latent victims are those who are more likely to be victims of other people, such as children and women.[1]

There are still women of domestic violence victims who try to hide the problems of the violence they experienced because they feel ashamed of the social environment and do not want to be considered a failure in their household.[2]The mindset that thinks of what happens in the family, even if it is an act of violence, is entirely a private household problem, often makes victims reluctant to complain about the violence that has happened to them. The victim felt taboo and thought that she would expose her own family to shame, especially in cases related to sexual violence. Moreover, there is a thought that when reporting the abuse to the police, the reporter can become multiple victims, which means that the victim must always repeat the unpleasant actions that have befallen him, starting at the Police to court proceedings so that it tends to increase suffering / pressure on the victim.

The issuance of Law Number 23 of 2004 concerning the Elimination of Domestic Violence (PKDRT Law) is expected to be the basis for prosecution, prevention as well as 
protecting victims of domestic violence without reducing the integrity and harmony of the household. In the terms of prosecution of acts of domestic violence, the police are at the forefront of handling cases of domestic violence, namely implementing law enforcement as regulated in Article 13 of Law Number 2 of 2002 concerning the Indonesian National Police. Although efforts have been made to prevent and prosecute cases of domestic violence by the police, the fact is that Domestic violence in Indonesia continues to occur, resulting in women experiencing suffering both physically and psychologically.

Providing protection for women and children which is also part of the main duties of the police as regulated in Article 13 of Law Number 2 of 2002, which is to provide protection, protection, and services to the community. As for the content of Article 13 of Law Number 2 of 2002, the main duties of the State Police of the Republic of Indonesia are (Article 13):

a. Maintaining security and public orders;

b. Enforcing the law, and

c. Providing protection, assurance, and services to the community.

Regarding the protection of victims of domestic violence by the police, it is confirmed in Article 10 letter a of Law No. 23 of 2004 concerning the Elimination of Domestic Violence states that: "Victims have the right to receive protection from their family, police, prosecutors, courts, advocates, social institutions, or other parties, either temporarily or based on the stipulation of a protection order from the court. "[2] Concerning the protection of victims of domestic violence, this paper will describe the legal protection of children who are victims of domestic violence.

\section{Method}

The methodology used in this research is normative research, which will use a descriptive type of research with a normative juridical approach.[3]based on the prevailing laws and regulations. In this writing, the authors conducted research using the descriptive analysis method using a form of library research.[4]

\section{Discussion}

Children are social creatures as well as adults, children also need someone to develop their abilities because children are born to be weak figures so that without assistance from others, children cannot reach a normal standard of life. Children are individuals who are still clean and sensitive to inducements from the environment. The definition of children is still a problem and often creates confusion, it is due to the absence of a clear and uniform understanding of both the laws and regulations in Indonesia and the opinion of scholars on this matter. However, based on Article 330, we can see the criteria for an immature person. Article 330 of the Civil Code states: "Minors are those who have not reached the age of twenty-one years, and have not previously been married". If the statutory regulation uses the term "immature", then it refers only to the Indonesian nation, with that term what is meant: all people who have not reached the even age of 21 years and have not previously been married. If the marriage is dissolved before the age of twenty-two, they do not return to the term "immature".

With due observance of the provisions of Article 330 of the Civil Code, the age limit so that a person is categorized as a child, namely those who have not reached the age of twenty- 
one and have not previously married. In Article 1 number 1 of Law Number 23 of 2002 concerning Child Protection, the definition of a child is someone who is not yet 18 (eighteen) years old, including children who are still in the womb. Meanwhile, the provisions of the Criminal Code do not provide an understanding of children but only provide an age limit. According to the provisions of Article 45 of the Criminal Code, the limit for children is people who are under 16 (sixteen years). Meanwhile, when viewed from the limitations of children in the Criminal Code as victims of crime as referred to in Chapter XIV of the provisions of Articles 290, 292, and 294 of the Criminal Code, they are less than 15 (fifteen) years of age. Article 1 paragraph (2) of Law No. 4 of 1979 on Child Welfare states that: "A child is someone who has not reached the age of 21 (twenty-one) years and has never been married. To determine the age limit of a child with certainty is quite difficult because the development of a person, both physically and psychologically, varies greatly from one another, even though a person is an adult, his behavior still shows signs of immaturity and vice versa ".[5]

Starting from the description above, for the definition of a child that can be used as a reference by the author, namely referring to the definition of children according to Law No. 23 of 2002 concerning Child Protection, where what is meant by children is "A person who is not yet 18 (eighteen), including the child who is in the womb".

The case phenomenon of domestic violence (KDRT) against women in Indonesia is very concerning. In response to this, the government continues to strive to deal with cases of domestic violence which have a very high incidence rate in Indonesia, one of which is by conducting the 2016 National Women's Life Experience Survey (SPHPN) to find out what forms of domestic violence are and what are the factors that cause the high incidence of violence. in the household that befell women, especially in physical and sexual violence, to find a way out in dealing with the problem.

The term violence is used to describe behavior, whether open (overt) or closed (covert), whether it is offensive or defensive, which is accompanied by the use of force to others. UU no. 23 of 2004, defines domestic violence as any act against someone, especially women, which results in suffering or suffering physically, sexually, psychologically, and / or negligence of the household, including threats to commit acts, coercion, or illegal deprivation of liberty within the scope of the family. Indeed, there is no single and clear definition relating to domestic violence. However, common basic domestic violence includes[6]:

a. physical violence, which is any action that causes death,

b. psychological violence, namely every action and speech that results in fear, loss of selfconfidence, loss of ability to act, and feelings of helplessness in women.

c. sexual violence, which is any act that includes sexual harassment to the point of forcing someone to have sexual intercourse without the consent of the victim or when the victim does not want to; and or having sexual relations in ways that are not reasonable or that the victim does not like; and or keep him away (isolated) from his sexual needs,

d. economic violence, which is any act that restricts a person (woman) from working inside or outside the home that produces money and / or goods; or let the victim work to be exploited; or neglect family members.

Children protection is all activities to guarantee and protect children and their rights so that they can live, grow, develop and participate optimally under human dignity and protection from violence and discrimination. The children protection system is regulated based on the Law of the Republic of Indonesia Number 35 of 2014, where Article 55 states that the Government and Regional Government (Pemda) are obliged to carry out the care, care, and social rehabilitation of abandoned children both inside and outside the institution.[7] 
Children's rights are human rights that must be guaranteed, protected, and fulfilled by parents, family, and society, government, and the state. According to the Law of the Republic of Indonesia Number 35 of 2014, the children's rights include:

a. Can live, grow, develop and participate fairly according to human dignity and receive protection from violence and discrimination.

b. Identity from birth.

c. To worship according to religion, think, and express according to the level of intelligence and age under the guidance of parents.

d. To find out about the parents, they are raised and cared for by their parents if for some reason the parents cannot guarantee the growth and development of the child, or the child is neglected, the child has the right to be cared for or adopted as a foster child or adopted child by another person under the provisions of the law. - applicable legislation.

e. Receive health services and social security according to physical, mental, spiritual, and social needs.

f. Receiving education and teaching in the context of personal development and intelligence level according to their interests and talents, children who must have excellence are also entitled to special education.

g. To express and hear his opinion, accept seek and provide information according to the level of intelligence and age for the sake of self-development following the values of decency and obedience.

h. To rest and take advantage of free time, associate with children of the same age as faith, recreation, and creating according to their interests, talents, and intelligence level to develop themselves.

i. Receive protection from discrimination, economic and sexual exploitation, neglect, cruelty, violence and persecution, injustice, and another mistreatment.

j. In the care of their parents, unless there is a reason and / or there is a valid legal rule indicating that the separation is in the best interests of the child and is the last consideration.

Whereas every child with a disability in addition to having the rights mentioned above has other rights, namely:

1. Receive inclusive education and or special education.

2. Receive rehabilitation, social assistance, and maintenance in the level of children's social welfare for children with disabilities.

Especially for children who are deprived of their liberty, apart from having the rights mentioned above, they have the right:

a. Receive humane treatment by paying attention to the needs according to age.

b. Separation from adults.

c. Providing legal assistance and other assistance effectively.

d. Enforcement of recreational activities.

e. Freedom from torture, punishment, or other cruel, inhuman, and degrading treatment of dignity and degree.

f. Avoidance of publication of his identity.

g. Providing justice before a juvenile court that is objective, impartial, and in a closed court session.

Domestic violence according to Law No. 23 of 2004 concerning regional government is every act against someone, especially women, which results in suffering or suffering physically, sexually, psychologically, and or neglecting the household, including threats to commit acts, coercion, or illegal deprivation of liberty within the scope of the household that 
violence against women is all acts of violence committed against women that have an effect or tendency to cause physical, sexual, and psychological harm and suffering to women, both adult women or girls and adolescents.[8]This includes threats, coercion or deliberately confining women's freedom. Acts of physical, sexual, and psychological violence can occur in the family or community.

Violence against wives in the household is a form of violence that often occurs against women and happens behind closed doors. This act is often associated with both physical and psychological torture by people who have a close relationship. The tendency for domestic violence to occur is due to social and cultural support factors where the wife is perceived as secondary and can be treated in any way. This occurs because of the transformation of knowledge obtained from the past, the wife must obey the husband's words, if the wife argues against the husband, be beaten. The culture in the husband's society is more dominant in the wife, there are acts of violence in the household that are considered a matter of privacy, the community should not interfere.

At present, with the enactment of the law against domestic violence approved in 2004, violence in the household is not only a husband and wife affair but has become a public affair. Families and communities can participate in preventing and monitoring when violence occurs in the household. Violence against wives in the household occurs because it is believed that the dominant society or culture today is patriarchy, where men are superior and women are inferior so that men are justified in dominating and controlling women. This makes women subordinate. In addition, there is a misinterpretation of gender stereotypes that have been socialized for a long time, where women are considered weak, while men are generally stronger. The Consequences of this violence can lead to physical, sexual, psychological, and / or domestic neglect,

The obligations and responsibilities of the State and the Government in child protection efforts are regulated in the Child Protection Law articles 21 to 24, namely: 1) Respect and guarantee the human rights of every child regardless of ethnicity, religion, race, class, gender, ethnicity, culture and language, the legal status of children, order of birth of children and physical and / or mental conditions; 2) Providing support for facilities and infrastructure in implementing child protection; 3) Ensuring the protection, maintenance, and welfare of children by taking into account the rights and obligations of parents, guardians, or other people who are generally responsible for children and supervise the implementation of child protection; 4) Ensure children to exercise their rights in expressing opinions according to the child '[9]

An anticipatory solution so that children do not become victims is to first consider this problem as a criminal act and a serious crime, of course, if this is already in the mindset of society it will immediately shape behavior to protect women and children. It needs to take an active step and try to expose this crime to its conclusion so that a deterrent effect for the perpetrator exists and sets a precedent for person / people who will become perpetrators of violence against women and children to think about these acts. Apart from that, I see that from a legislative perspective, in the framework of updating the Criminal Code (KUHP),

\section{Conclusion}

Violence against children in the household environment has certain characteristics that make it hard to enforce the law. Since the meaning of a child is so important, the state along with the community must strive to provide adequate protection for children so that they can 
grow and develop physically, mentally, and socially good. The juridical obligations of the state will depend on the positive laws that exist in the country. Providing adequate protection for a child, efforts to protect children must be supported by the existence of an effective and comprehensive child protection law. Legal protection for child victims of domestic violence has not been explicitly regulated in the National Criminal Law.

\section{Reference}

[1] R. Yulia, Victimology: Legal Protection of Crime Victims, 2nd ed. Yogyakarta: Graha Ilmu, 2013.

[2] Ministry of Law and Human Rights, "Law Number 23 of 2004 concerning Elimination of Domestic Violence (UU PKDRT)." 2004.

[3] DL Sonata, "NORMATIVE AND EMPIRICAL LEGAL RESEARCH METHODS: SPECIFIC CHARACTERISTICS OF LEGAL RESEARCH METHODS," FIAT JUSTISIAJournal of Law., vol. 8, no. 1, Nov. 2015, doi: 10.25041 / fiatjustisia.v8no1.283.

[4] MH Dr. johnny ibrahim, SH.,Normative Law Research Theory \& Methodology. 2006.

[5] A. Kamil and Fauzan, Law, Protection and Adoption of Children in Indonesia. Jakarta: Raja Gravindo Persada, 2008.

[6] and U. Better Care Network, The Alliance for Child Protection in Humanitarian Action, "PROTECTION OF CHILDREN DURING THE COVID-19 Child PANDEMIC and Alternative Care," 2020.

[7] Herawati, Hazilina, and F. Zar'in, "Feasbylity Study of Legal Protection for Early Childhood Competitive Advantage," J. Obs. J. Educator. Early childhood, vol. 5, no. 2, pp. 1625-1634, 2021, doi: 10.31004 / obssesi.v5i2.932.

[8] Ikhsan, HS Disemadi, K. Syukri, and Pujiyono, "Child Protection Efforts in Criminal Justice in the Era of Enforcement of the 'New Normal' during the COVID-19 Pandemic in Indonesia," J. Legal Studies., vol. 9, no. 2, pp. 225-242, 2020.

[9] Rini Fitriani Marlina, "Legal Protection for Child Victims of Domestic Sexual Violence," Mercatoria, vol. 2, no. 1, pp. 26-34, 2009. 